\title{
The Effect of Sodium Chloride on Hybrid Taxodium Selections
}

\author{
Anna Koonce1, Edward Bush², David Creech ${ }^{3}$ \\ ${ }^{1}$ California Polytechnic State University, San Luis Obispo, CA, USA \\ ${ }^{2}$ Louisiana State University, Baton Rouge, LA, USA \\ ${ }^{3}$ Department of Agriculture, Arthur Temple College of Forestry and Agriculture, Stephen F. Austin State University, \\ Nacogdoches, TX, USA \\ Email: akoonce@calpoly.edu,ebush@agcenter.lsu.edu,dcreech@sfasu.edu
}

How to cite this paper: Koonce, A., Bush, E. and Creech, D. (2020) The Effect of Sodium Chloride on Hybrid Taxodium Selections. Journal of Environmental Protection, 11, 408-420.

https://doi.org/10.4236/jep.2020.115024

Received: December 29, 2019

Accepted: May 22, 2020

Published: May 25, 2020

Copyright (C) 2020 by author(s) and Scientific Research Publishing Inc. This work is licensed under the Creative Commons Attribution International License (CC BY 4.0).

http://creativecommons.org/licenses/by/4.0/

\section{(cc) (i) Open Access}

\begin{abstract}
Saltwater intrusion is a major cause of coastal erosion. New hybrid bald cypress species have been shown to exhibit salinity tolerance compared to native bald cypress species. Planting these hybrids, or Nanjing Bot Garden genotype (NBG), trees where their roots can stabilize soil and preserve land may reduce coastal erosion in areas subjected to saltwater intrusion. The purpose of this experiment was to determine whether or not selected bald cypress NBG genotype tree species survive better than native bald cypress trees in areas inundated with saline water. Leaves were harvested, dried and analyzed for their elemental concentration. NBG genotype trees excluded more sodium than native bald cypress trees. NBG genotype tree roots were also less effected by brackish water. Finally, the growth of the NBG genotype trees and the control were measured. All NBG genotype trees tested showed growth while the control trees maintained little or no growth, and a decrease in tree height in sodic soil. If these NBG genotype trees are subjected to a surge of brackish water, NBG genotype bald cypress trees may be used to stabilize soil that may be otherwise subject to coastal erosion.
\end{abstract}

\section{Keywords}

Salt Water Intrusion, Brackish Water, Coastal Erosion, Taxodium Genotypes

\section{Introduction}

Water is crucial for all forms of plant life. Living plants can contain up to $95 \%$ of water [1]. Saltwater intrusion occurs when excessive amounts of fresh water are pumped from aquifers at a faster rate than it can be replenished or mixed with saline water sources. Increasing populations in urban and rural areas have in- 
creased the demand for fresh water. To meet this demand, fresh water is being extracted from surface water and wells at a pace faster than it can be replenished [2]. This situation causes saltwater to intrude into water areas previously filled by freshwater. Research has proven that saltwater intrusion occurs due to the different densities of fresh and saltwater. The varying densities cause the two waters to mix as saltwater rises, thus the salty ocean water infiltrates freshwater, making the freshwater into brackish water, a mixture of fresh and saltwater [3]. Plants living in areas containing brackish water experience osmotic stress so that when a plant is surrounded by saltwater, it might end up in a negative osmotic pressure [4]. As a result, the plant will die of dehydration or ionic toxicity because it does not receive the freshwater it needs, or it declines from a nutrient imbalance. This is often seen in marshes and swamps. A swamp is defined as a place with woody plants such as cypress trees or mangroves, whereas a marsh has no woody plants. Both swamps and marshes must flood often and are areas of vast vegetation [5]. Research has established that certain vegetation found in marshes and swamps that osmotically can adjust from fresh to brackish water may help solve the issue of coastal erosion. Erosion is the gradual destruction of soil by natural forces such as water, wind or ice and has a negative effect on the environment. Half the topsoil on the planet has been lost in the last one hundred and fifty years, mostly due to erosion [6]. One woody tree, the bald cypress tree, is known to be particularly useful in Louisiana swamps for preventing erosion because their extensive root systems ability to survive inundation will stabilize soil, slowing down erosion [7]. However, bald cypress trees are also susceptible to saltwater intrusion. Saltwater inundates freshwater systems, causing trees to slowly decline which reduces soil stability and impacts the swamp ecosystem. Researchers hope that new NBG genotype selections of cypress trees may have a higher survival rate in increased levels of salinity, making it possible to restore bald cypress populations back in impacted areas, and thus reducing erosion in areas of saltwater intrusion [8]. The objective of this experiment was to study three $\mathrm{t}-\mathrm{NBG}$ genotype bald cypress species to determine which selection survives and thrives in soil with a high salt concentration in attempt to reduce coastal erosion created by saltwater intrusion.

One ecosystem subjected to saltwater intrusion where many bald cypress trees live is a swamp. Often confused with a marsh, a swamp has woody plants such as mangroves or cypress trees [5]. A swamp is an area of land permanently filled or covered with water. Trees are a vital part of swamps, and swamps are often even named for the trees that live in them. For a long period of time, people considered swamps to be a wasteland. Arbitrarily filling and draining swamps created a negative environmental impact on the swamp ecosystem. Now, ecologists understand that swamps are a transition between land and water; thus, considered a natural resource that contains large reservoirs for water, while filtering nutrients and soil solids.

To understand the need for saltwater tolerant NBG genotype trees, it is necessary to comprehend ideal conditions for freshwater plants. Plants need water, 
nutrients, clean air, light, correct temperature, and space to expand. Plant growth is dependent on the essential plant nutrients for plant growth. The roots of a plant gather these essential nutrients from the soil surrounding its roots. These plant elements are used for plant growth and development and are essential for photosynthesis and reproduction [9]. Plants in a swamp are used as a biological filter reducing high loads of nutrients and suspended solids.

There are many ways a freshwater tree may adapt itself in sodic soils. One way is exclusion, where a plant excludes salt through filtration in the roots. The root membrane in these plants prevents salt from infiltrating the roots while still allowing water. These filters are susceptible to breaking down when waterlogged [10]. Another method plants use is defoliation. Defoliation includes the plant destroying or having widespread loss of leaves in order to rid itself of salt. The plant gathers the salt in its leaves and when the leaves fall off, there is ideally no excess salt in the plant's system [11].

The elements in sea salt, sodium and chloride, are destructive to freshwater plants for several reasons. Sodium $(\mathrm{Na})$, and chlorine $(\mathrm{Cl})$, are the two elements that make up salt. Though an excessive amount of any nutrient can harmful to a plant, sodium and chloride can be phytotoxic. Sodium chloride dissolves easily in water, making it especially harmful to freshwater organisms living in water and soil [12]. Small quantities of chlorine in water can slow plant growth, but in large amounts chlorine can be phytotoxic. Many plant species can tolerate moderate rates of chlorine, however plants that are more sensitive to chlorine can be damaged [13].

Freshwater is infiltrated by salt through the process of saltwater intrusion. Saltwater intrusion is defined as the induced flow of seawater into freshwater aquifers primarily caused by various types of groundwater development near the coast. Channelization is an example of a cause of saltwater intrusion. While man-made channels bring in boats, they also provide more entry ways for saltwater to intrude. Another cause is groundwater being pumped excessively from aquifers forming a cone of depression in the freshwater area of the aquifer and leaving an area for saltwater to seep in. Induced gradients may cause saltwater to move from the ocean towards the well, making the freshwater in the well unstable. Louisiana marshes and swamps have also been negatively impacted by coastal subsidence causing saltwater intrusion [14]. Saltwater intrusion differs from the typical inland flow of freshwater from inland aquifers which replenishes areas so that the costal discharge areas move to the sea. The natural movement of freshwater to the sea should prevent saltwater from entering aquifers. However, groundwater pumping and development prevents freshwater from flowing towards the costal discharge areas, which permits saltwater to intrude into the freshwater zone of the coastal aquifers [15]. Saltwater intrusion kills plants through osmotic stress or osmotic shock. When the salt concentration of fluids around the plant cells change suddenly, the cells undergo extreme osmosis. Osmosis draws out substrates or any solute in the supernatant water [16].

Saltwater intrusion is an international problem because of many people waste 
or overuse freshwater. After being used, groundwater that has been pumped is then treated and discarded into the ocean. This process results in millions of gallons of freshwater being removed from aquifers every day and that freshwater ultimately being replaced by saltwater. Some cities suffering from extreme saltwater intrusion include Savannah, Georgia, Miami and Tampa Bay, Florida, and Los Angeles, California. Saltwater intrusion led to the abandonment of more than fifteen hundred wells between 1990 and 1997 near the Laizhou Gulf in China, and since 1940 more than one hundred wells have been abandoned just on the Cape May Peninsula in New Jersey. The government currently restricts water use from backyard wells simply in an effort to control saltwater intrusion in Perth, Australia.

Additionally, saltwater intrusion is one large cause of Earth's erosion. Half of the topsoil on the planet has been lost in the last one hundred and fifty years [6]. Almost two thirds of the human population live within $400 \mathrm{~km}$ of the ocean shoreline, while just over half live within $200 \mathrm{~km}$ of the shoreline [7]. With humans living so close to the disappearing shore, it is just a matter of time before many people's homes are underwater. A solution to the issue of erosion caused by saltwater intrusion may save countless lives and properties from irrevocable damage.

The effects of soil erosion do not stop at loss of fertile land. Soil erosion leads to increased pollution, sedimentation in streams and rivers harms species living there, and even increases flooding because degraded lands are often less able to hold onto water. Vegetation on the shoreline provides a natural barrier to erosion, though this barrier is rapidly disappearing [6]. Swamps containing bald cypress trees are fundamental for protecting some coastal areas from extreme coastal erosion and flooding which occurs during hurricanes. The swamps could be called the "speed bump" for a storm coming inland from the sea because the power of the storm is diminished when it must move over the swamps and bayous before it enters the mainland [17].

Bald cypress trees have many uses other than for protection from erosion and natural disasters. The rot-resistant heartwood found in mature trees is used to make fence posts, doors, flooring, caskets, cabinetry, boats, and many other wood products. Bald cypress filter pollutants and prevent the pollutants from spreading. Frogs, salamanders, and toads use these tree ecosystems for breeding. Wood ducks may use a tree's hollow trunk to nest in, while catfish spawn in the submerged hollow logs. Raptors commonly use the treetops to nest [7]. This tree species is invaluable in its contribution to wetland ecosystems worldwide.

In order to determine how to protect this productive species and the coastline, Taxodium genotypes were tested in this project. The Taxodium distichum (L.) Rich. var. distichum (Bald Cypress) is native to the south eastern USA. This species lives in humid and hot areas, but have been known to survive through temperatures as cold as $-29^{\circ} \mathrm{F}$. Taxodium survive in areas intermittently flooded, but only with freshwater [18]. Another species is the Taxodium distichum var. mexicanum (Carriere Gordon) (Montezuma Cypress) which commonly lives in areas in Mexico. The Montezuma Cypress lives in mostly arid and hot areas and 
has moderate drought tolerance. This species can live in saline conditions [19]. The final trees used were the pond cypress which thrives in moist to wet soils that are not seasonally flooded. They are able to handle draught but prefer less fertile sandy soils when compared to the other two species [20]. A cross between the botanical varieties created by the Nanjing Bot Garden produces seedlings and selections from those could perhaps survive better in both flooded areas and sodic areas that have a broad temperature range.

Why are these qualities necessary to reduce erosion caused by saltwater intrusion? An NBG genotype between the Montezuma cypress and bald cypress could potentially achieve several objectives in the war against erosion: Taxodium genotypes may be able to live in submerged conditions, meaning that it could be planted in areas already eroding and solve erosion at its source by stabilizing the soil. An NBG genotype may be able to live in saline conditions, meaning the species could be planted in areas directly affected by saltwater intrusion and not be as affected. An NBG genotype may be able to live in a broad range of temperatures, meaning it could be planted around the world and be a relatively easy fix for a large problem. An NBG genotype will likely live for a long time, meaning the trees provide a long-term solution erosion in the areas they are planted.

In this experiment the researcher will study the $T$. distichum in comparison to three NBG genotypes of the Taxodium species as they react to an increased amount of salty water in their environment. These NBG genotypes may have traits adopted from their parents [21]. If any of the NBG genotype trees can thrive in salty situations given their inherited salt and flood tolerance, they may present the solution to not only saltwater intrusion, but also to the loss of land caused by intrusion.

\section{Materials and Methods}

Fontainebleau State Park in Mandeville, Louisiana was the site selected for this experiment because of erosion saltwater intrusion. Ten one-gallon container plants of each of the four genotypes were planted in a color coordinated pinwheel design. Each tree was spaced six feet apart with a water source in the center for the first 14 days of establishment. Five of each species was placed on each side of an imaginary diameter but the trees are otherwise randomized.

Immediately after planting, the trees were watered and then measured. One month after the trees were planted, leaves were harvested dried at $65 \mathrm{C}$ for 48 hours and ground into a powder and analyzed by the LSU soil testing lab. Leaf tissue $\mathrm{Na}, \mathrm{Fe}$ and $\mathrm{Mn}$ was measured. Quality ratings were measured on a $0 \%$ $100 \%$ plant health scale every 4 weeks. One year after the trees were planted, the soil in which they were planted was tested again for its salt concentration. After this, their height was measured again. This same day, leaf samples were taken again from the trees and the element concentration of the leaves was measured again. The heights and element concentrations before and after a year of the plants being established were then compared. 


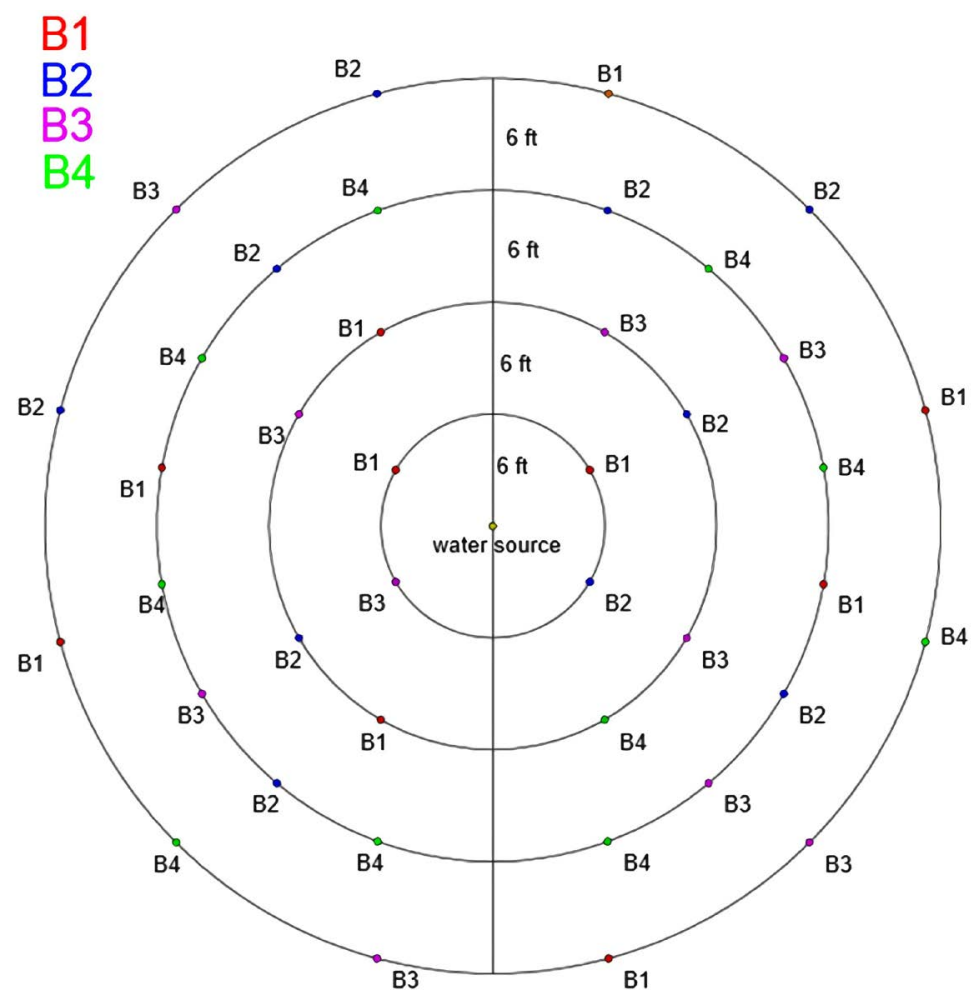

It should be noted that between the time trees were planted in field conditions and the one-year mark, they experienced intermittent flooding, tropical storms, and below freezing temperatures.

Electrolyte leakage study was performed to determine root tolerance to brackish water from the control bald cypress species and two species of NBG genotypes. First, the trees were harvested and their roots were cleaned. Twelve root samples of the three tree selections were harvested and placed into $50 \mathrm{~mL}$ plastic containers with distilled water. Roots were then placed into their respective salt concentrations of either 0 ppt salt, $10 \mathrm{ppt}$ salt, or $20 \mathrm{ppt}$ salt. The roots in the plastic containers were emptied into the labeled Erlenmeyer flasks and randomly placed on a circular orbiter.

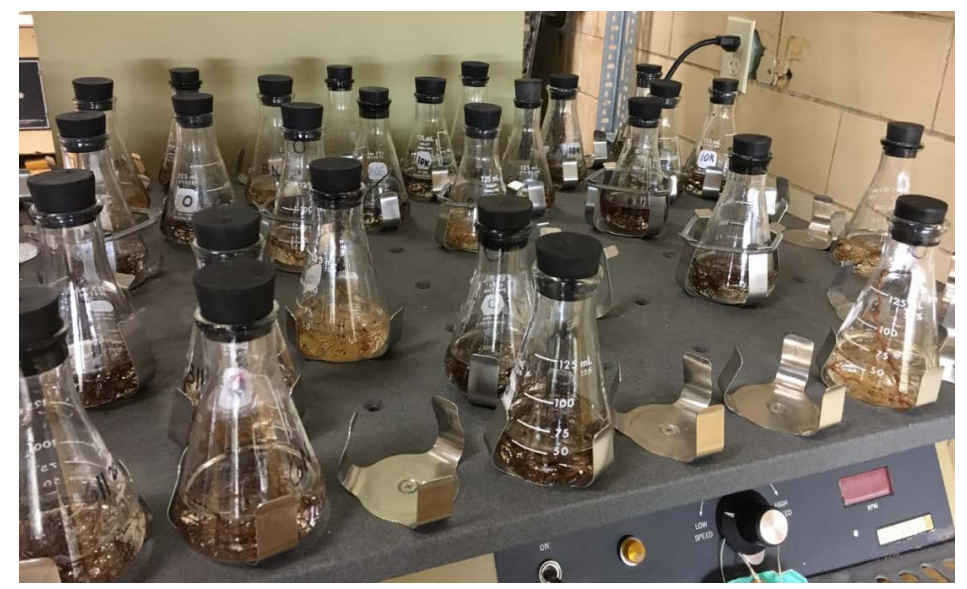

Photo of circular orbiter holding flasks. 
The circular orbiter was placed on a low setting and the roots were left to slowly rotate in their salt concentration for 48 hours. Then, the roots were taken from the flasks, rinsed over a sifter with distilled water, and placed back into the flask with distilled water this time. Following another 48 hours, the roots were taken out of the water and root leakage of sodium was measured with a TDS meter. This procedure was determined in preliminary research [22]. After each experiment, data was collected, and the research was transferred into an excel chart to be analyzed.

\section{Results and Discussion}

It has been determined that different NBG genotypes may be the solution to the global issue of saltwater intrusion as they have shown to be significantly more tolerant to saline conditions than native bald cypress trees. It is observed that the T-406 genotype is the most successful at excluding salt based on Figure 1 and it can therefore be concluded that this genotype would be best suited to combat saltwater intrusion around the world.

The first phase of the experiment involved testing the leaves of each individual tree for the concentration of each element it contained and giving each a health rating. By proving that each of the genotype's leaves had a significantly lower sodium concentration than the native bald cypress tree, it became a possibility that trees in this genotype used exclusion as a method for omitting salt from their systems. Also, by comparing the salt concentrations of the leaves after one month and one year, the researcher was able to conclude through results that the new genotype trees become more resistant to saltwater intrusion as time passes as seen in Figure 1 and Figure 2. Finally, in Figure 3 and Figure 4, the health rating of almost all hybrids was shown to be statistically higher than the control both times they were rated with the T-406 being rated most healthy both times.

As an addition to the first phase of research, foliage samples from the same

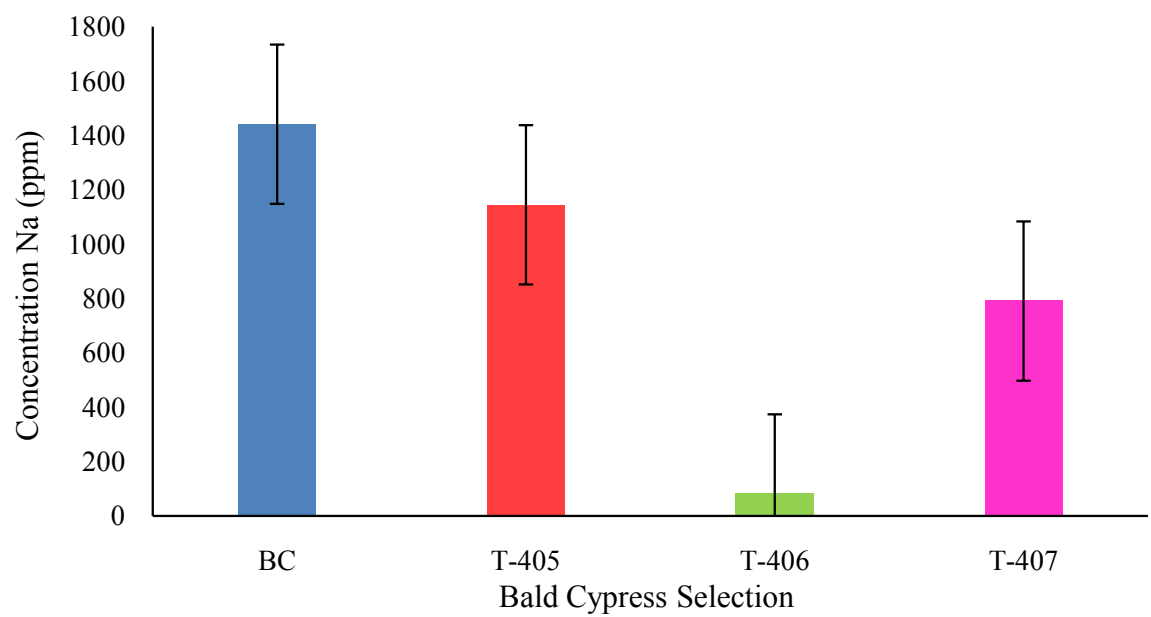

Figure 1. The concentration of sodium present in the foliage November 2016 Fontainebleau planting site (error bars represent significance at the 0.05 level). 


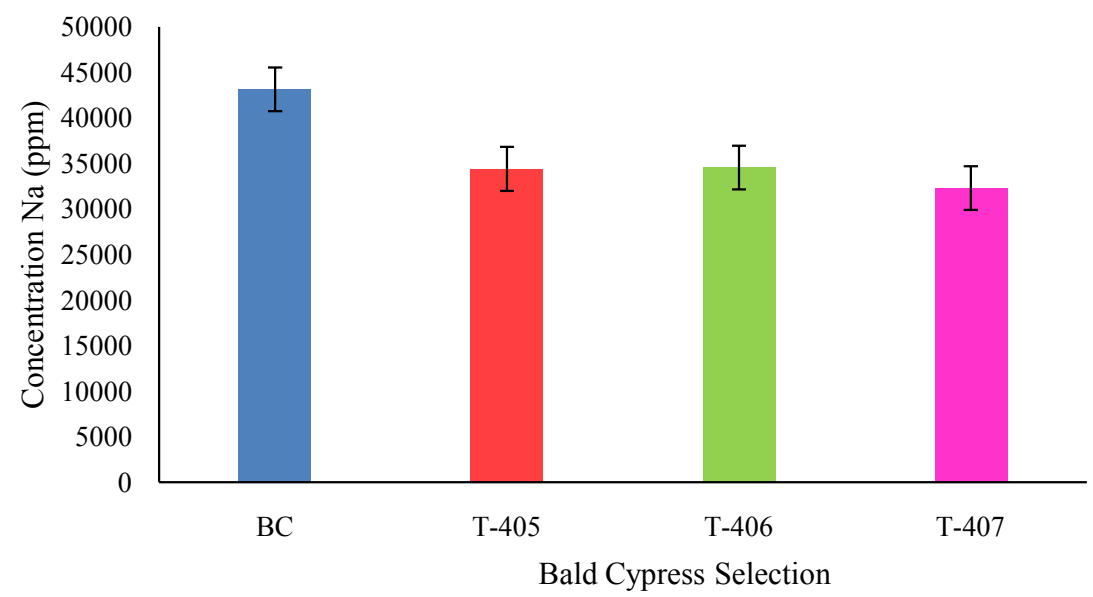

Figure 2. The concentration of sodium present in the foliage at Fontainbleu November 29, 2015 (error bars represent significance at the 0.05 level).

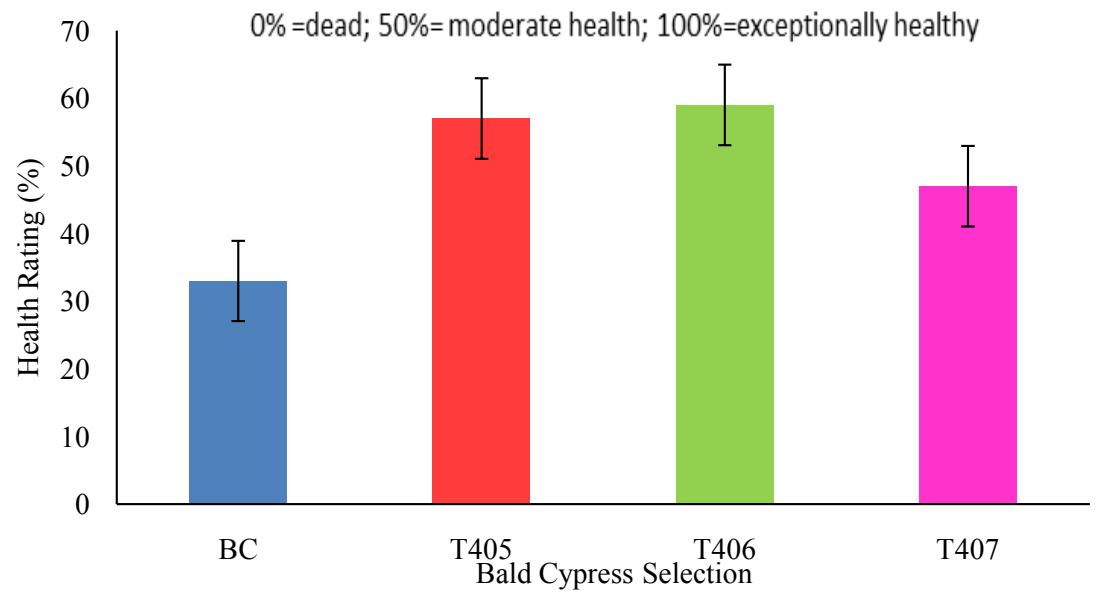

Figure 3. Influence of saline soil on the growth of bald cypress trees November 1, 2015 (error bars represent significance at the 0.05 level).

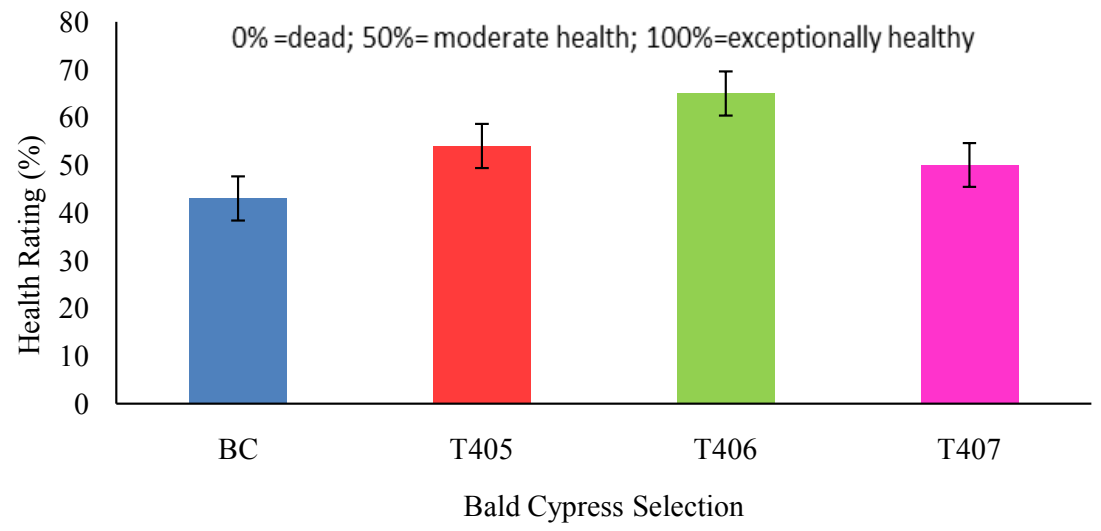

Figure 4. Influence of saline soil on the growth of bald cypress trees November 29, 2015 (error bars represent significance at the 0.05 level).

NBG genotypes in the Galveston area were collected, tested for sodium content, and analyzed as a comparison to the Fontainebleau trees. These samples all had 
much lower sodium content than the Fontainebleau trees, and showed the T-405 as having significantly less sodium in foliage samples as seen in Figure 5. This may be due to little to no exposure to intermittent flooding and could be basis for future research.

The growth of the three NBG genotypes trees and the bald cypress control trees was documented at their initial planting and one year later. After comparing the two times in Figure 1 and Figure 2, it was discovered that almost all new genotype trees experienced significant growth in the one-year time span while the control trees experienced little growth or even a decline in height (tip dieback). NBG genotype trees experience overall significant height increase which is further proof that the NBG genotypes are capable of thriving when planted in salt-challenged soil.

The second phase of research was conducted in a lab on the roots of two NBG genotype species and one control species. This experiment ended with several interesting observations seen in Figures 6-8. First, the bald cypress control tree

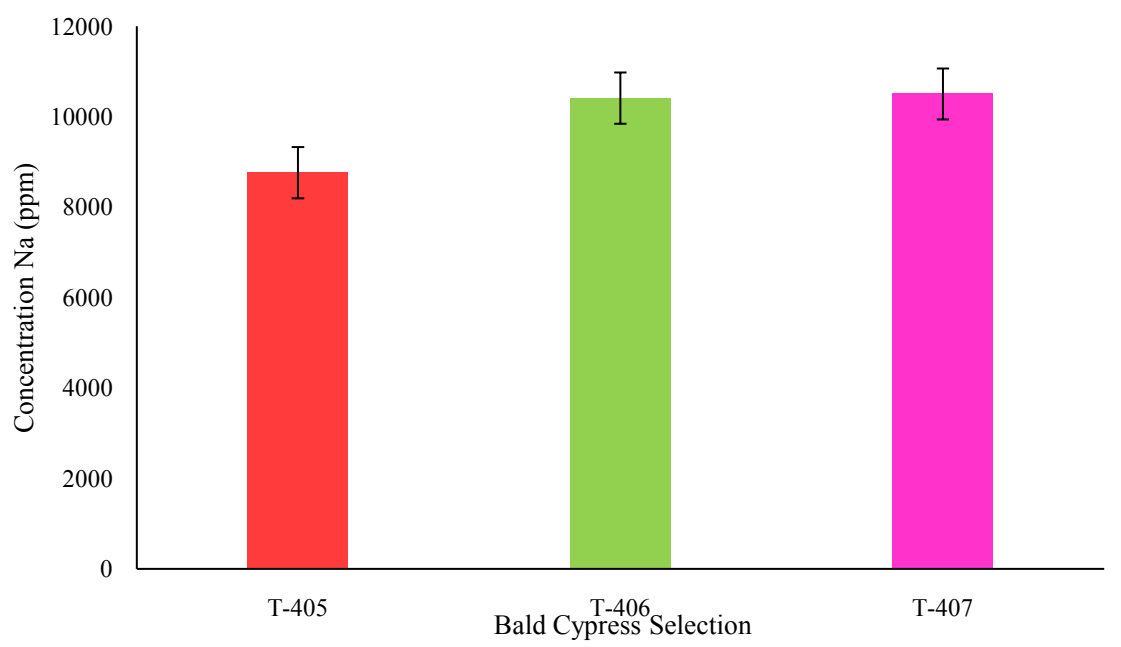

Figure 5. The concentration of sodium present in the foliage November 2016 Galveston planting site (error bars represent significance at the 0.05 level).

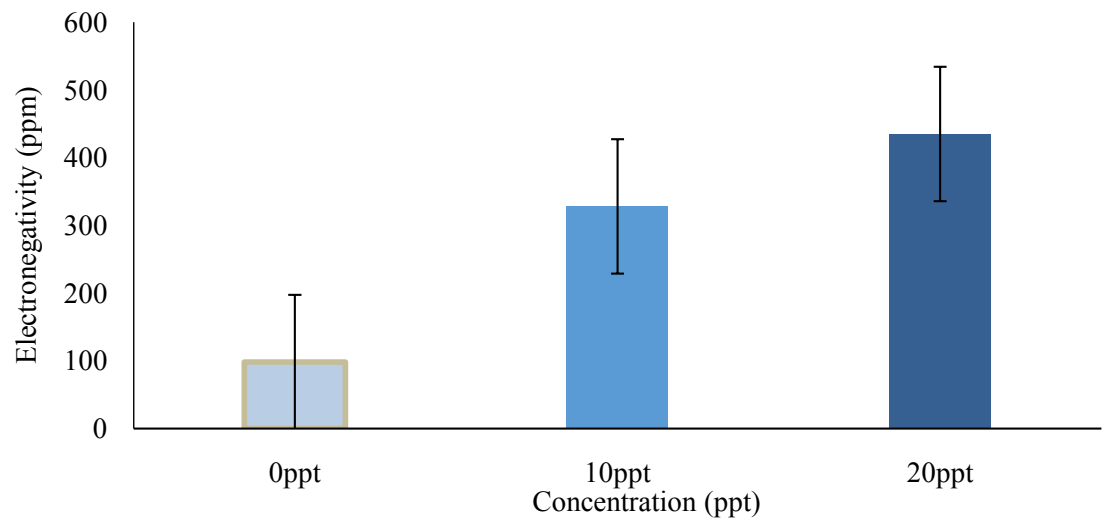

Figure 6. Comparison of root electroconductivity in the control cypress when soaked in various concentrations of sodium chloride for 48 hours (error bars represent significance at the 0.05 level). 


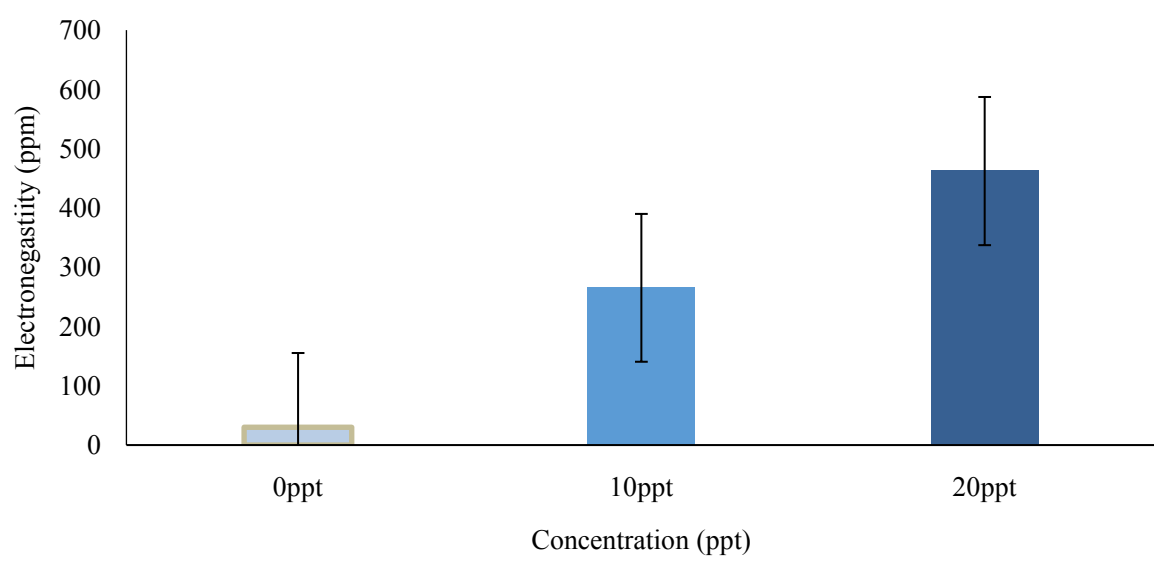

Figure 7. Comparison of root electroconductivity in the T-406 hybrid when soaked in various concentrations of sodium chloride for 48 hours (error bars represent significance at the 0.05 level).

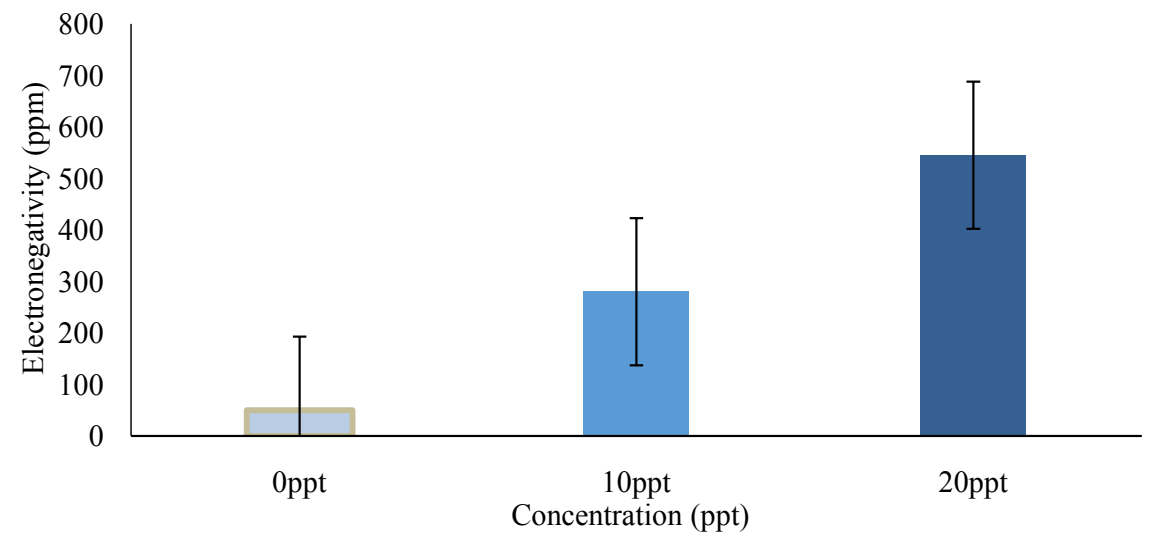

Figure 8. Comparison of root electroconductivity leakage in the T-407 hybrid when soaked in various concentrations of sodium chloride for 48 hours (error bars represent significance at the 0.05 level).

roots jumping from a significant difference in $0 \mathrm{ppm}$ and $10 \mathrm{ppm}$ to no significant difference between concentrations $10 \mathrm{ppm}$ and $20 \mathrm{ppm}$ means that immediately after exposure to saltwater, the roots began to deteriorate. The NBG genotype roots, on the other hand, had no significant difference in the root leakage between any concentrations. This uniformity is crucial in the understanding that the NBG genotype trees are more tolerant to brackish water and can withstand saline conditions.

The NBG genotype trees may have thrived in saline conditions for many reasons. One adaptation method is defoliation. Defoliation includes the plant having harmful leaves of some sort which causes the plant to cause widespread loss of its leaves. In the case of this experiment, the plant would gather the harmful salt in its leaves and when the leaves fall off, there would ideally be no excess salt in the plant's system. Another method the trees may have used is exclusion. This method involves the plant having the ability to exclude salt through filtration in the roots. The root membrane in these plants prevents salt from infiltrating the 
roots while still allowing water assimilation. Scientists Schachtman et al. (1990) determined the variations of salt tolerance in hexaploid wheat (Triticum aestivum). They identified highly tolerant accessions that may be useful for improving the salt tolerance of bread. To discover which accessions would be tolerant to the salt the researchers looked at the concentration of $\mathrm{Na}+$ in the plant's leaves. By testing the leaves, the researchers were examining the plants' ability to exclude salt in their surrounding soil so that it would not be present in the plants' leaves [23]. Therefore, data suggests that exclusion was probably the method of sodium exclusion in this experiment.

With the growing problem of saltwater intrusion around the world, the need for a solution is needed greatly. Research done on coastal tree species in 1990 showed the exact destructive potential brackish water could truly have. Coastal tree species exposure to saline flooding resulted in foliage damage, and enormous reductions in carbon assimilation rates. The trees responded morphologically through gas exchange rate reductions. Once the water's salinity increased to over $50 \mathrm{~mol}^{-3}$ (3ppt), researchers observed leaf burning and carbon assimilation rates of $84 \%$ in some seedlings. This experiment, along with others proving it correct, demonstrated the crippling effects saltwater intrusion has on leaves, net carbon assimilation, and seedling mortality [24]. If nothing is done about this issue, certain habitats may be completely lost along with the natural range of those habitats.

The idea of using salt tolerant plants as a preventative method for erosion has been put in place before. In fact, many areas already use salt tolerant plants as their main preventative method for eroding land. Species tolerant to saline soils or salt spray are typically grasses, shrubs, or short deciduous trees with a need for well drained soils. The few tall trees that are tolerant to saline soils or saltwater spray require well drained soils [25].

The novelty of this research lies in the fact that NBG genotype trees or any form of trees capable of being submerged are largely unused as a method of erosion prevention. If groups of the NBG genotype trees were instated along coastlines experiencing erosions due to saltwater intrusion, said erosion may be prevented by the trees' root matrix holding soil. The NBG genotypes are ideal for areas most susceptible to severe erosion as they may grow up to 50 - 100 feet, can grow in a variety of climates and soils, are capable of surviving in submerged conditions, and survive in extreme weather. These NBG genotypes may offer a plant-based solution for erosion in saline conditions.

\section{Conclusions}

A series of conclusions are apparent through the several experiments conducted in this research.

1) All NBG genotypes were able to exclude salt from their leaves more successfully than the control bald cypress trees both one month and one year after the trees were planted. 
2) All NBG Genotypes are able to grow in one year in saline conditions while the control bald cypress tree did not.

3) The roots of the NBG genotype trees deteriorate less in brackish water than the control bald cypress species' roots.

4) The T-406 genotype was the most successful out of the NBG genotypes at excluding salt in foliage tests, root evaluation, and growth.

5) Over time, NBG genotypes may become more resistant to saline conditions.

Overall, NBG genotype trees seem to be more tolerant to increased levels of sodium chloride than native bald cypress trees. This offers hope that trees may be altered to be better adapted to prevent wetland erosion.

\section{Conflicts of Interest}

The authors declare no conflicts of interest regarding the publication of this paper.

\section{References}

[1] Adams, C.R. and Early, M.P. (2004) Principles of Horticulture. Elsevier Butterworth-Heinemann, Amsterdam. https://doi.org/10.4324/9780080480350

[2] Cassardo, C. and Jones, J. (2011) Managing Water in a Changing World. Water, 3, 618-624. http://www.mdpi.com/2073-4441/3/2/618 https://doi.org/10.3390/w3020618

[3] Saltwater Intrusion. http://kanat.jsc.vsc.edu/student/spatafora/setup.htm

[4] Saltwater Intrusion: The Parts You Can't See. http://www.coastalreview.org/2015/03/saltwater-intrusion-the-parts-you-cant-see

[5] What Is the Difference between a Swamp and a Marsh? http://beachchairscientist.com/2010/09/13/what-is-the-difference-between-a-swam p-and-a-marsh

[6] Soil Erosion and Degradation. http://www.worldwildlife.org/threats/soil-erosion-and-degradation

[7] Bald Cypress. https://www.nwf.org/Wildlife/Wildlife-Library/Plants/Bald-Cypress.aspx

[8] Salt Tolerance of Southern Baldcypress (1997). http://www.nwrc.usgs.gov/factshts/fs92_97.pdf

[9] Phipps, N. (2011) How Do Plants Grow—Things Plants Need to Grow. http://www.gardeningknowhow.com/special/children/how-plants-grow.htm

[10] D5 Sodic Soil Management (2004) In Vegetable SOILpak. New South Wales Department of Primary Industries, New South Wales.

[11] Defoliate. http://dictionary.reference.com/browse/defoliation?s=t

[12] Water Treatment Solutions. http://www.lenntech.com/periodic/elements/cl.htm

[13] What Is the Effect of Chlorinated Water on Plant Growth? http://scienceline.ucsb.edu/getkey.php?key=2271

[14] Boesch, D.F., Levin, D., Nummedal, D. and Bowles, K. (1983) Subsidence in Coastal Louisiana: Causes, Rates, and Effects on Wetlands. U.S. Fish and Wildlife Service, Division of Biological Services, Washington DC. FWS/OBS-83/26. 30 p. 
[15] Pump/Recharge Rate Affects Saltwater Intrusion. http://www.solinst.com/resources/papers/101c4salt.php

[16] Osmotic Shock—Definition, Glossary, Details-Oilgae. http://www.oilgae.com/ref/glos/osmotic_shock.html

[17] Bald Cypress Trees in the United States. http://www.monumentaltrees.com/en/trees/baldcypress/deep_south

[18] Whilhite, L. and Toliver, J. (n.d.) Taxodium distichum (L.).

[19] Gilman, E.F. and Watson, D.G. (1994) Taxodium mucronatum Montezuma Baldcypress. http://hort.ufl.edu/database/documents/pdf/tree_fact_sheets/taxmuca.pdf

[20] Wright, J.J. (2019) Pond Cypress vs. Bald Cypress. https://www.hunker.com/12493716/pond-cypress-vs-bald-cypress

[21] Chappell, M. (2013) Plant Breeding and Evaluation. SNA Research Conference, Vol. 58, 261-261. http://www.sna.org/Resources/Documents/13resprocsec10.pdf

[22] Bush, E., Wilson, P., Shepard, D. and McCrimmon, J. (2000) Freezing Tolerance and Nonstructural Carbohydrate Composition of Carpetgrass (Axonopus affinis Chase). HortScience, 35, 187-189. https://doi.org/10.21273/HORTSCI.35.2.187

[23] Schachtman, D., Munns, R. and Whitecross, M. (1990) Variation in Sodium Exclusion and Salt Tolerance in Triticum tauschii. Crop Science, 31, 992-997. https://doi.org/10.2135/cropsci1991.0011183X003100040030x

[24] Appleton, B., Greene, V., Smith, A., French, S., Kane, B., Fox, L., Gilland, T., et al. (2015) Trees and Shrubs That Tolerate Saline Soils and Salt Spray Drift. Virginia Polytechnic Institute and State University, Blacksburg.

[25] Pezeshki, S., Delaune, R. and Patrick, W. (1990) Flooding and Saltwater Intrusion: Potential Effects on Survival and Productivity of Wetland Forests along the U.S. Gulf Coast. Forest Ecology and Management, 33-34, 287-301.

https://doi.org/10.1016/0378-1127(90)90199-L

\title{
Acronyms and Definitions
}

\author{
Phytotoxic-toxic to plants \\ TDS meter-Total Dissolved Solids. \\ NBG-Nanjing Bot Garden \\ BC-Baldcypress - Taxodium distichum (L.) Rich.var. distichum \\ PC-Pondcypress-Taxodium distichum var. imbricarium (Nutt.) Croom \\ MC-Montezuma cypress-Taxodium distichum var. mexicana Gordon
}

